\title{
The Effect of Liquidity and Profitability on the Capital Structure as the Moderator Variable of Subsector Retail Companies Listed on Indonesian Stock Exchange
}

\author{
Hantono \\ Faculty of Economics and Business, Accounting Study Program Universitas Pelita Harapan, Indonesia \\ hantono_78@yahoo.com
}

\begin{abstract}
The purpose of this research is to prove and to analyze the effect of liquidity and profitability on the capital structure as the moderator variable of the subsector retail companies listed on Indonesian Stock Exchange in the period of 2011-2015. The population in this research are the listed 16 companies. Using purposive sampling, 10 out of 16 companies are selected as the sample of this research. The data used in this research is secondary data by gathering the necessary information from idx such as the financial report in 2011-2015. The methods that are used in this research to analyze the correlation between the independent variable and dependent variable are multiple regression and assumption testing. In conclusion, it is shown that simultaneously, using $f$ test, independent variables; Cash Turnover and Company Size effect the Return on Assets accordingly with the Debt to Equity Ration as the moderator variable. Partial research result using $t$ test shows that Cash Turnover and Company size effect the Return on Assets partially with Debt of Equity as the moderator variable.
\end{abstract}

\section{Keywords}

cash turnovers, company size; return on assets, debt to equity ratio

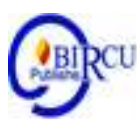

\section{Introduction}

A company that operates in parallel with its development always needs additional capital. When a company is built, the owner can decide which capital source is going to be used whether it is only from common index capital or long time liability. Every decision that is made on the capital source always has its effect. Capital structure is the comparison between liabilities and the company's capital. One of the important matter that often faced by the manager of a company is to decide on the right balance between liabilities and capital. The following is the condition of the capital structure which is being projected with the debt to equity ratio of the subsector retail companies listed on the Indonesian Stock Exchange in the period of 2011-2015. 
Table 1. Debt To Equity Ratio

\begin{tabular}{|c|c|c|c|c|c|}
\hline \multirow{2}{*}{ Code } & \multicolumn{5}{|c|}{ Year } \\
\cline { 2 - 6 } & $\mathbf{2 0 1 1}$ & $\mathbf{2 0 1 2}$ & $\mathbf{2 0 1 3}$ & $\mathbf{2 0 1 4}$ & $\mathbf{2 0 1 5}$ \\
\hline alka & 4.32 & 1.69 & 3.05 & 2.96 & 1.33 \\
\hline almi & 2.16 & 2.2 & 3.18 & 4.23 & 2.87 \\
\hline baja & 1.86 & 2.19 & 3.83 & 4.61 & 4.86 \\
\hline bton & 0.28 & 0.28 & 0.26 & 0.18 & 0.22 \\
\hline gdst & 0.31 & 0.46 & 0.34 & 0.57 & 0.47 \\
\hline inai & 4.13 & 3.73 & 5.06 & 6.34 & 4.54 \\
\hline jksw & -1.75 & -1.69 & -1.64 & -1.72 & -1.6 \\
\hline jprs & 0.29 & 0.14 & 0.03 & 0.06 & 0.09 \\
\hline lion & 0.21 & 0.16 & 0.19 & 0.42 & 0.4 \\
\hline lmsh & 0.71 & 0.31 & 0.28 & 0.25 & 0.18 \\
\hline pico & 1.98 & 1.98 & 1.88 & 1.71 & 1.45 \\
\hline
\end{tabular}

It is seen from the table above that debt to equity ratio of the company with JKSW stock symbol had a significant decrease compared to the other companies' stock symbols. This shows that the profit that the company gained was having a decrease which caused the investor in the stock market did not add any fund to their issuer. Therefore, this will affect the company such as lowering the company's performance in achieving its goals.

The purposes of this research are: Firstly, it is to test and to analyze whether the current ratio will affect the Return on Assets with debt to equity ratio as the moderator variable of the subsector retail companies listed on Indonesia Stock Exchange in the period of $2011-2015$. Secondly, it is to test and to analyze the cash turnover that will affect the Return on Assets with debt to equity ratio as the moderator variable of the subsector retail companies listed on Indonesia Stock Exchange in the period of 2011-2015. Thirdly, it is to test and to analyze the size of the company which will affect Return on Assets with debt to equity ratio as the moderator variable of the subsector retail companies listed on Indonesia Stock Exchange in the period of 2011 - 2015. Fourthly, it is to test and to analyze the current ratio, the cash turnover and the company size that will affect the Return on Assets with debt to equity ratio as the moderator variable of the subsector retail companies listed on Indonesian Stock Exchange in the period of 2011-2015.

\subsection{Problem Formulation}

The problem formulations of this research are:

1. Will the cash turnover affect the Return on Assets with the debt to equity ratio as the moderator variable of the subsector retail companies listed on Indonesia Stock Exchange in the period of 2011 - 2015?

2. Does the company size affect the Return on Assets with debt to equity ratio as the moderator variable of the subsector retail companies listed on Indonesia Stock Exchange in the period of $2011-2015$ ?

3. Do the cash turnover and the company size affect the Return on Assets with debt to equity ratio as the moderator variable of subsector retail companies listed on Indonesia Stock Exchange in the period of $2011-2015$ ? 


\subsection{Research Purpose}

The purposes of this research are:

1. To test and to analyze if the cash turnover affects the Return on Assets with debt to equity ratio as the moderator variable of the subsector retail companies listed on the Indonesia Stock Exchange in the period of 2011 - 2015.

2. To test and to analyze if the company's size affects Return on Assets with debt to equity ratio as the moderator variable of the subsector retail companies listed on Indonesia Stock Exchange in the period of 2011-2015

3. To test and to analyze if the cash turnover and company size affect Return on Assets with debt to equity ratio as the moderator variable of the subsector retail companies listed on Indonesia Stock Exchange in the period of $2011-2015$.

\section{Review of Literature}

\subsection{Cash Turn Over}

According to Kasmir (2012:140), cash turnover has the function to measure the level of working capital required by the company to pay bills and the finance sales. Which means, this ratio is used to measure the level of cash availibilty to pay the bills (debt) and the other costs that are associated with the sale.

\subsection{Company Size}

According to Najmudin (2011: 316), company size is that generally, the large scale company is easier to obtain debts compared to the small companies because of the trust level given by the creditor to the big companies. According to Halim (2015: 125), the larger the size of a company, the greater also the tendency of a company to use foreign capital. This is because the large company needs large funds too to support their operational and one of the alternative fulfillment is to get foreign capital if the company owner's capital is insufficient.

\subsection{Return on Assets}

According to Husnan (2006: 73), Return on Assets can also be said as the profitability of the company which is a ratio that measures how much profit owned by the owner of the capital. According to Murhadi (2013:64), Return on Assets is the reflection of how much the return generated for the shareholders over each dollar of money is being invested. According to Ichsan (2021) Return on Asset (ROA) is one form of profitability ratio, by using after various capital costs and total assets owned by banks, it can see the ability of a company to be able to earn profit / profit. Because, return on assets is a measurement tool used in the ability of the company and assess the effectiveness to get profit and profit.

\subsection{Debt to Equity Ratio}

According to Jusuf (2088: 55), debt to ratio is the ratio between total liabilities to the total of equity. This ratio shows the extent of the capital to guarantee all of the liabilities. According to Harahap (2013:303), debt to equity ratio illustrates the extent to which the owner's capital can cover the debts to outsiders. 


\subsection{Previous Research}

Yuke (2005), did a research with the title "Factors that Affect the Capital Structure of Go Public Manufactures in Jakarta Stock Exchange". The result of research showed that partially, the company size had a significant effect towards the capital structure and the profitability had the significant positive effect towards the capital structure. While simultaneously, the company size, business risk, asset growth, profitability and corporate ownership structure affect the Capital Structure.

Thomi Irvan (2016), did a research with the title "The Effect of Profitability and Liquidy on the Capital Structure of Insucrance Companies Listed on Indonesia Stock Exchange (IDX) in the Period of 2012 - 2014". The partial research result showed that the variables of profitability and liquidity did not affect DER. While simultaneously, profitability and liquidity did not affect DER.

Nadzirah (2016) did a research with the title "The Effect of Company Size and Profitability on the Capital Structure of Property and Real Estate Companies Listed on Indonesia Stock Exchange in The Period of 2012-2014”. The result of this research partially shows that company size and profitability have positive and significant effect.

\section{Research Methods}

This research tends to be correlational which explain the association between the research's variables. Using secondary data such as documents and financial reports that are related to this research. The data is obtained from Indonesia Stock Exchange website, derived from the annual financial report to be sampled in the period of 2011-2015 which is downloaded from the official website of Indonesia Stock Exchange namely www.idx.co.id.

The population in this research are the 16 subsector retail companies listed on Indonesia Stock Exchange in the period of 2011-2015. Using purposive sampling, 10 out of 16 companies are selected to be the samples. The technique of the data collection in this research uses documentation study, that is by downloading the financial report of the subsector retail companies listed on Indonesia Stock Exchange in the period of 2011-2015. Moderator Variable is a variable that strengthens or weakens the correlation between one variable to another.

There are 2 equation models in general, which are:

\section{First Method}

Moderation regression equation with iteration test:

$\mathrm{Y}=\mathrm{a}+\mathrm{b} 1 \mathrm{X} 1+\mathrm{b} 2 \mathrm{X} 2+\mathrm{b} 3 \mathrm{X} 1 \mathrm{X} 2+\mathrm{e}$

Description:

$$
\begin{aligned}
& \mathrm{Y}=\text { Profitability } \\
& \mathrm{A}=\text { Constant } \\
& \mathrm{b} 1=\text { Regression coefficient for cash turnover } \\
& \text { b2 }=\text { Regression coefficient for company size } \\
& \text { b3 = Regression coefficient for moderator } \\
& \mathrm{X} 1=\text { Cash Turnover X2 = Company size X1.2 = Interaction }
\end{aligned}
$$

\section{Second Method}

a. Absolute Difference Value. This is done by finding the difference of absolute value standardized between two independent variables.

b. If the absolute difference value between two independent variables are positive significant, that means the variable moderates the correlation between the independent variable and the dependent variable. 
Below is the research model framework:

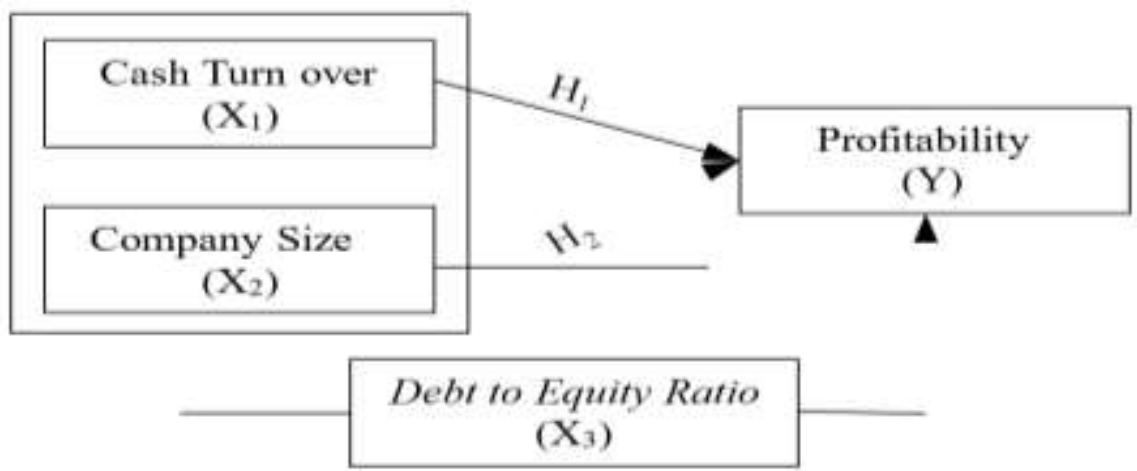

Figure 1. Conceptual Framework

The analyses of this research data are using the first two analyses, by using the descriptive analysis and statistical analysis such as multiple linear regression analysis.

\section{Results and Discussion}

\subsection{Statistical Analysis}

Before doing the statistical analysis by using multiple linear regression analysis, it is important to fulfill the requirements of classical assumption test. The following is the explanation of the classical assumption test:

\section{a. Normality Test}

Normality test is done in order to test whether the disturbing variable or the residual variable has a normal distribution in the regression model (Ghozali, 2011). There are two methods to detect whether the data is normally distributed or not by using graph analysis (scatterplot), and statistical analysis (Kolmogrov-Smirnov).

The following is the result of classical assumption test based on the normality test by using Kolmogrov-Smirnov:

Table 1. Kolmogorov Smirnov (First Regression Model)

\begin{tabular}{|c|c|c|}
\hline & & Unstandardized Residual \\
\hline $\mathrm{N}$ & & 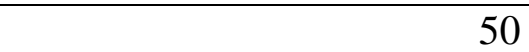 \\
\hline \multirow[t]{2}{*}{ Normal Parameter ${ }^{a \cdot b}$} & Mean & .0000000 \\
\hline & Std. Deviation & .08817823 \\
\hline \multirow[t]{3}{*}{ Most Extreme Differences } & Absolute & .129 \\
\hline & Positive & .129 \\
\hline & Negative & .073 \\
\hline Kolomogorov-Smirnov Z & & .913 \\
\hline Asymp.Sig.(2-tailed) & & .375 \\
\hline
\end{tabular}

a. Test distribution is Normal

b. Calculated from data

Source: Result of Data Processing, 2020 
Table 2. Kolmogorov Smirnov (Second Regression Model)

\begin{tabular}{|c|c|c|}
\hline & & Unstandardized Residual \\
\hline $\mathrm{N}$ & & 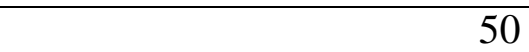 \\
\hline \multirow[t]{2}{*}{ Normal Parameter ${ }^{a \cdot b}$} & Mean & .0000000 \\
\hline & Std. Deviation & .08804228 \\
\hline \multirow[t]{3}{*}{ Most Extreme Differences } & Absolute & .184 \\
\hline & Positive & .184 \\
\hline & Negative & -.097 \\
\hline Kolomogorov-Smirnov Z & & 1.302 \\
\hline Asymp.Sig.(2-tailed) & & .067 \\
\hline
\end{tabular}

a. Test distribution is Normal

b. Calculated from data

Source: Result of Data Processing, 2020

Based on the table of One sample Kolmogrov-Smirnov, it is seen that the value of Asympg.Sig (2-tailed) is above 0,05 or above $5 \%$. This shows that the data is normally distributed.

\section{b. Heteroscedasticity Test}

Heteroscedasticity Test purpose is to test whether there is a variance inequality of the residual in one observation to the another observation in the regression model (Ghozali, 2016: 134-138). In order to see or to detect the occurrence of heteroscedasticity in this research, the researcher uses the scatterplot chart.

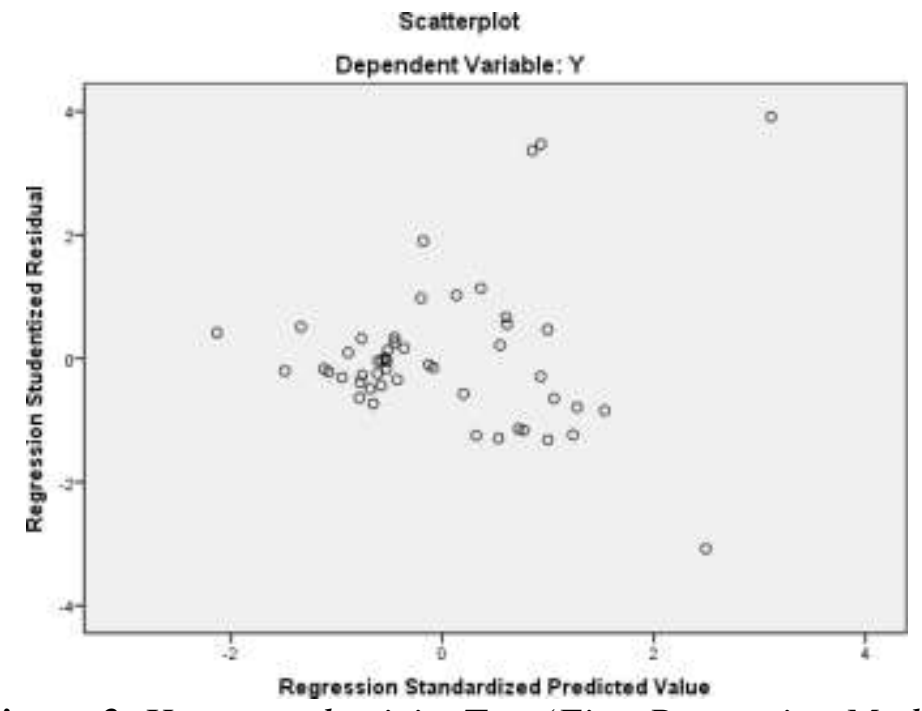

Figure 2. Heteroscedasticity Test (First Regression Model)

Source: Result of Data Processing, 2020 


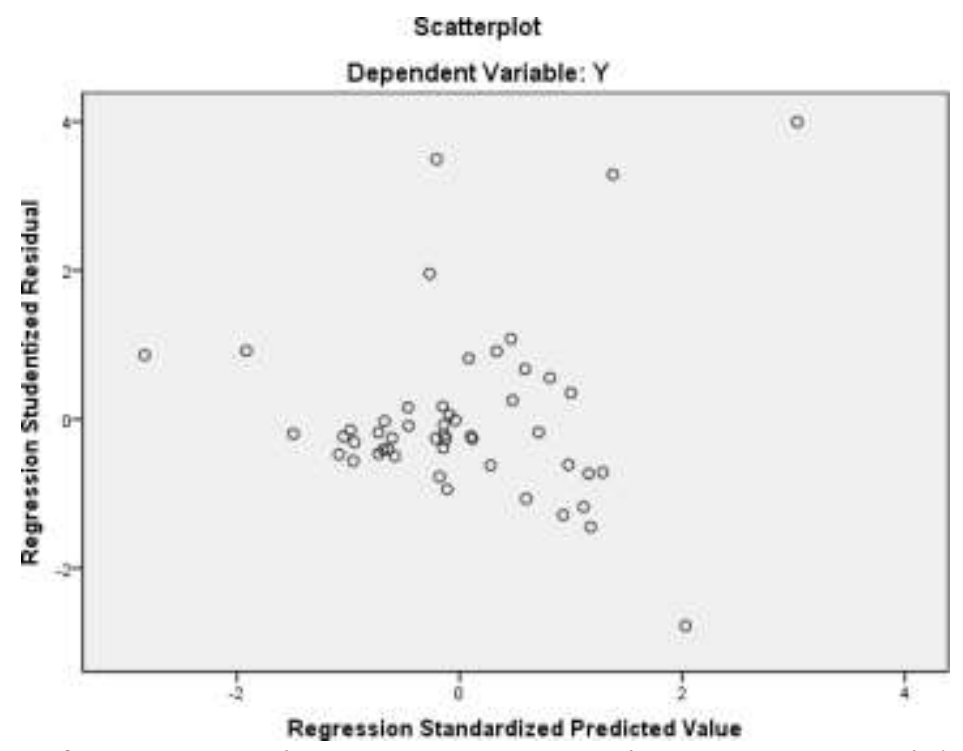

Figure 3. Heteroscedasticity Test (Second Regression Model)

Source: Result of Data Processing, 2020

From the scatterplot chart, both outputs appear to have dots spreading randomly either from above or below the number zero (0) on the $\mathrm{Y}$ axis. The dots do not gather in a place. Thus from the scatterplot chart, it is concluded that there is no heteroscedasticity happened in the regression model.

\section{c. Multicollinearity Test}

The purpose of Multicollinearity Test is to test whether there is a correlation between independent variables in the regression model (Ghozali, 2016: 103-104). Detecting the occurrence of multicollinearity in the regression model can be done by looking at the tolerance and the variance inflation factor with the following assumptions:

Table 3. Multicollinearity Test (First Regression Model)

Coefficients $^{\mathrm{a}}$

\begin{tabular}{|l|l|r|r|}
\hline \multicolumn{2}{|c|}{ Model } & \multicolumn{2}{c|}{ Collinearity Statistics } \\
\cline { 3 - 4 } \multicolumn{2}{|c|}{} & Tolerance & \multicolumn{1}{c|}{ VIF } \\
\hline & $\mathrm{X}_{1}$ & .383 & 2.613 \\
& $\mathrm{X}_{2}$ & .771 & 1.297 \\
& $\mathrm{X}_{3}$ & .468 & 2.136 \\
& $\mathrm{X}_{4}$ & .264 & 3.790 \\
\hline
\end{tabular}

a. Dependent Variable: Y

Source: Result of Data Processing, 2020

Based on the table of multicollinearity test, the output of the first regression shows that the tolerance value is below 0.05 and the VIF value is above 10 . Thus, it can be indicated that the symptom of multicollinearity occurs which causes the researcher performs the second test as a moderator or amplifier variable for the following multicollinearity test: 
Table 4. Multicollinearity Test (Second Regression Model) Coefficients $^{\mathrm{a}}$

\begin{tabular}{|c|c|c|c|}
\hline \multirow{2}{*}{\multicolumn{2}{|c|}{ Model }} & \multicolumn{2}{|c|}{ Collinearity Statistics } \\
\hline & & Tolerance & VIF \\
\hline 1 & $\mathrm{Z}$ Score $\left(\mathrm{X}_{1}\right)$ & .987 & 1.014 \\
\hline & Z Score $\left(X_{2}\right)$ & .967 & 1.034 \\
\hline & $\mathrm{Z}$ Score $\left(\mathrm{X}_{3}\right)$ & .977 & 1.023 \\
\hline
\end{tabular}

a. Dependent Variable: Y

Source: Result of Data Processing, 2020

It is seen that on the table above, the output in second regression involves the moderator variable. Therefore, there is no symptom of multicollinearity occurs in this research.

\section{d. Autocorrelation Test}

According to Ghozali (2016: 107 - 108), the purpose of autocorrelation is to test whether there is a correlation between the error in the $t$ period and the error in $t-1$ period (before). If the correlation occurs, then it is named problem autocorelation. The method used to detect the occurance or the absence of autocorrelation is by using Durbin Watson test (DW test).

Table 5. Durbin Watson (First Regression Model)

Model Summary ${ }^{\mathrm{b}}$

\begin{tabular}{|c|c|r|l|r|r|}
\hline Model & R & R Square & $\begin{array}{l}\text { Adjusted R } \\
\text { Square }\end{array}$ & $\begin{array}{l}\text { Std. Error of } \\
\text { the Estimate }\end{array}$ & Durbin-Watson \\
\hline 1 & $.493^{\mathrm{a}}$ & .243 & .176 & .09187 & 2.123 \\
\hline
\end{tabular}

a. Predictors: (Constant), X4,X2, X3, X1

b. Dependent Variable: Y

Source: Result of Data Processing, 2020

Table 6. Durbin Watson (Second Regression Model)

Model Summary ${ }^{b}$

\begin{tabular}{|c|c|r|r|r|r|}
\hline Model & $\mathrm{R}$ & R Square & $\begin{array}{l}\text { Adjusted R } \\
\text { Square }\end{array}$ & $\begin{array}{r}\text { Std. Error of } \\
\text { the Estimate }\end{array}$ & Durbin-Watson \\
\hline 1 & $.475^{\mathrm{a}}$ & .226 & .175 & .09190 & 2.156 \\
\hline
\end{tabular}

a. Predictors: (Constant), X3,X1, X2

b. Dependent Variable: Y

Source: Result of Data Processing, 2020

According to the table above, the DW values are 2.210 and 2.123. Furthermore, it shows that there is no symptom of autocorelation occurs in this research. After passing the classical assumption test, the researcher performs the multiple linear regression which are consisted of coefficient of determination (R2), group test (F-test) and individual test (Ttest):

\subsection{Coefficient of Determination ( $R 2)$}

The purpose of the coefficient of determination is to see how far the ability of a model in explaining the dependent variable 
Table 7. Coefficient of Determination (R2) (First Regression Model)

Model Summary ${ }^{b}$

\begin{tabular}{|c|c|r|l|r|r|}
\hline Model & R & R Square & $\begin{array}{l}\text { Adjusted R } \\
\text { Square }\end{array}$ & $\begin{array}{l}\text { Std. Error of } \\
\text { the Estimate }\end{array}$ & Durbin-Watson \\
\hline 1 & $.493^{\mathrm{a}}$ & .243 & .176 & .09187 & 2.123 \\
\hline
\end{tabular}

a. Predictors: (Constant), X4,X2, X3, X1

b. Dependent Variable: Y

Source: Result of Data Processing, 2020

Table 8. Coefficient of Determination (R2) ( Second Regression Model)

Model Summary ${ }^{\mathrm{b}}$

\begin{tabular}{|c|c|r|r|r|r|}
\hline Model & $\mathrm{R}$ & R Square & $\begin{array}{l}\text { Adjusted R } \\
\text { Square }\end{array}$ & $\begin{array}{c}\text { Std. Error of } \\
\text { the Estimate }\end{array}$ & Durbin-Watson \\
\hline 1 & $.475^{\mathrm{a}}$ & .226 & .175 & .09190 & 2.156 \\
\hline
\end{tabular}

a. Predictors: (Constant), Zscore (X3),Z Score (X1), Zscore (X2)

b. Dependent Variable: Y

Source: Result of Data Processing, 2020

According to the table of Model Summary, the value of R square is 0.243 and after using the moderator variable, the value of R-square becomes 0.226 . Thus, the residual of both R-square values outside this research and the strengthening of the number are seen after the moderator value is inserted in this research.

\subsection{Group Test (F Test)}

The F Test purpose is to test if the variable of cash turnover and company size affect the Return on Assets in the first regression model or whether the variables of the cash turnover and the company size affect the Return on Assets simultaneously if there is capital structure moderator variable in the second regression model. Both of the model results can be seen below:

Table 9. F Test (First Regression Model )

ANOVA $^{b}$

\begin{tabular}{|ll|r|r|r|c|c|}
\hline & Model & Sum of Squares & \multicolumn{1}{c|}{ df } & Mean Square & F & Sig. \\
\hline 1 & Regression & .122 & 4 & .031 & 3.617 &, $012^{\mathrm{b}}$ \\
& Residual & .380 & 45 & .008 & & \\
Total & .502 & 49 & & & \\
\hline
\end{tabular}

a. Predictors: (Constant), X4, X2, X3, X1

b. Dependent Variable: Y

Source: Result of Data Processing, 2020

Table 10. F Test (Second Regression Model)

ANOVA ${ }^{b}$

\begin{tabular}{|ll|r|r|r|c|c|}
\hline \multicolumn{1}{|c|}{ Model } & Sum of Squares & df & Mean Square & F & Sig. \\
\hline 1 & Regression & .113 & 3 & .038 & 4.475 &, $008^{\mathrm{a}}$ \\
& Residual & .389 & 46 & .008 & & \\
\cline { 2 - 6 } & Total & .502 & 49 & & & \\
\hline
\end{tabular}

a. Predictors: (Constant), Zscore(X2), Zscore(X1), Zscore(X2)

b. Dependent Variable: Y

Source: Result of Data Processing, 2020 
Based on the output of the second regression above, it is seen that the significant value is less than 0.05 . Thus, the capital structure moderates both of the variables in this research.

\subsection{Individual Test (t Test)}

The purpose of $t$ Test is to test whether the cash turnover variable and the company size affect individually or partially on Return on Assets in the first regression output or whether the variables of the cash turnover and company size affect partially on Return on if there is capital structure moderate variable in the second regression output. Both of regression outputs can be seen as below:

Table 11. $t$ Test (First Regression Model)

Coefficients $^{\mathbf{a}}$

\begin{tabular}{|cl|r|r|r|r|r|}
\hline \multirow{2}{*}{ Model } & \multicolumn{2}{|c|}{$\begin{array}{c}\text { Unstandardized } \\
\text { Coefficients }\end{array}$} & \multicolumn{2}{c|}{$\begin{array}{c}\text { Standardized } \\
\text { Coefficients }\end{array}$} & \multirow{2}{*}{$\mathrm{t}$} & \multirow{2}{*}{ Sig. } \\
\cline { 3 - 4 } & \multicolumn{1}{|c|}{$\mathrm{B}$} & \multicolumn{1}{c|}{ Std. Error } & \multicolumn{1}{c|}{ Beta } & & \\
\hline 1 & (Constant) & 1.849 & .594 & & 3.116 & .003 \\
& $\mathrm{X}_{1}$ & -.001 & .001 & -.458 & -2.186 & .034 \\
& $\mathrm{X}_{2}$ & -.060 & .020 & -.438 & -2.966 & .005 \\
& $\mathrm{X}_{3}$ & .011 & .006 & .352 & 1.859 & .070 \\
& $\mathrm{X}_{4}$ & -.019 & .018 & -.256 & -1.016 & .315 \\
\hline
\end{tabular}

a. Dependent Variable : Y

Source: Result of Data Processing, 2020

Table 12. $t$ Test (Second Regression Model)

Coefficients $^{\mathrm{a}}$

\begin{tabular}{|c|c|c|c|c|c|c|}
\hline & \multirow[t]{2}{*}{ Model } & \multicolumn{2}{|c|}{$\begin{array}{l}\text { Unstandardized } \\
\text { Coefficients }\end{array}$} & \multirow{2}{*}{$\begin{array}{c}\text { Standardized } \\
\text { Coefficients }\end{array}$} & \multirow[t]{2}{*}{$\mathrm{t}$} & \multirow[t]{2}{*}{ Sig. } \\
\hline & & $\mathrm{B}$ & Std. Error & & & \\
\hline 1 & (Constant) & .103 & .013 & & 7.908 & .000 \\
\hline & Zscore $\left(\mathrm{X}_{1}\right)$ & -.003 & .013 & -.292 & -2.232 & .030 \\
\hline & Zcsore $\left(\mathrm{X}_{2}\right)$ & -.038 & .013 & -.371 & -2.809 & .007 \\
\hline & Zscore $\left(\mathrm{X}_{3}\right)$ & -.038 & .013 & .213 & 1.626 & .111 \\
\hline
\end{tabular}

a. Dependent Variable : Y

Source: Result of Data Processing, 2020

Based on the t table above, therefore:

a. First Regression Model

Based on the research result, it is shown that partially the value of $t$ arithmetic is 1.016 and t table is 2.228, which means $t$ arithmetic < $t$ table. Meanwhile, the significant value is 0.315 which is bigger than 0.05 . This means the capital structure does not moderate both variables in this research.

b. Second Regression Model

Based on the partial test result, $t$ arithmetic is 1.626 with a significant value of 0.111 , the value of $\mathrm{t}$ table is 2.228 . This means $\mathrm{t}$ arithmetic $<\mathrm{t}$ table with the significant value of 0.111 , which is bigger than 0.05 . Therefore, it is concluded that capital structure does not moderate both of the variables in this research.

This research is in line with research that was done by Thomi Irvan (2016). The partial research result showed that the variables of profitability and liquidity did not affect DER. 
On the other hand, this research is not in line with Yuke (2005) and Nadzirah (2016). The partial research result showed that company size and profitability has a positive and significant effect on the capital structure.

\section{Conclusion}

The conclusion of this research is that the first and the second regression models simultaneously show the variable of capital structure affects and moderates both of the variables in this research. While partially, both of the regression models in this research show that capital structure does not moderate both of the variables in this research.

\section{References}

Ghozali, Imam.(2016).Aplikasi Analisis Multivariate dengan Program IBM SPSS 21. Semarang: Badan Penerbit Universitas Diponegoro.

Husnan, Suad dan Enny Pudjiastuti. (2006) Dasar-Dasar Manajemen Keuangan. Yoyakarta: Penerbit UPP STIM YKPN, 2006.

Harahap, Sofyan Syafri. (2013).Analisis Kritis atas Laporan Keuangan. Jakarta : PT Raja Grafindo Persada.

Halim, Abdul. (2015).Manajemen Keuangan Bisnis : Konsep dan Aplikasinya. Edisi Pertama. Jakarta : Mitra Wacana Media.

Ichsan, R. N., et al. (2021). Determinant of Sharia Bank's Financial Performance during the Covid-19 Pandemic. Budapest International Research and Critics Institute-Journal (BIRCI-Journal). P. 298-309.

Irvan, Thomi. (2016).Pengaruh Profitabilitas dan Likuiditas Terhadap Strukur Modal Perusahaan Asuransi Yang Terdaftar di Bursa Efek Indonesia (BEI) Periode 2012 2014, JOM FISIP, Vol.3, No.2. Oktober, Universitas Riau.

Jusuf, Jopie. (2008).Analisis Kredit untuk Account Officer". Jakarta : PT.Gramedia Pustaka Utama.

Kasmir.(2012).Analisis Laporan Keuangan.Cetakan Kelima. Jakarta : Rajagrafindo Persada.

Murhadi, Werner R. (2013).Analisis Laporan Keuangan : Proyeksi dan Valuasi Saham”. Jakarta: Penerbit Salemba Empat.

Prabansari, Y., dan Kusuma, H. (2005).Faktor-Faktor Yang Mempengaruhi Struktur Modal Perusahaan Manufaktur Go Public di Bursa Efek Jakarta. Sinergi, Edisi khusus on finance: $1-15$.

Najmudin.(2011).Manajemen Keuangan dan Aktualisasi Syar'iyyah Modern”.

Yogyakarta : Penerbit Andi.

Nadzirah, Fridayana Yudiaatmaja, Wayan Cipta.(2016).Pengaruh Ukuran Perusahaan dan Profitabilitas Terhadap Struktur Modal Pada Perusahaan Property and Real Estate yang Terdaftar di Bursa Efek Indonesia Periode 2012 - 2014”. E-Journal Bisma, Universitas Pendidikan Ganesha, Volume 4. 